\title{
Effects of reducing and postponing controlled-release urea application on soil nitrogen regulation and maize grain yield
}

\author{
Pengtao $\mathrm{ji}^{1}$, Yujuan Peng ${ }^{1}$, Yongwei Cui ${ }^{2}$, Xiangling $\mathrm{Li}^{3}$, Peijun Tao ${ }^{1}$, Yuechen Zhang ${ }^{1^{*}}$ \\ (1. College of Agronomy, Hebei Agricultural University/State Key Laboratory of North China Crop Improvement and Regulation, \\ Baoding 071001, Hebei, China; \\ 2. Academy of Agricultural Planning and Engineering, Ministry of Agriculture and Rural Affairs, Beijing 100125, China; \\ 3. College of Agronomy and Biotechnology, Hebei Normal University of Science \& Technology/Hebei Key Laboratory of \\ Crop Stress Biology, Qinhuangdao 066004, Hebei, China)
}

\begin{abstract}
Controlled-release urea (CRU-N) fertilizer application is a solution to improve the utilization rate of nitrogen (N), reduce economic costs and improve crop yields. It is significant to study the effects of release CRU-N reduction and the combined application of conventional urea on soil $\mathrm{N}$ control and the large-scale maize planting system. In this study, the effects of controlled-release nitrogen fertilizer reduction and postponement on soil nitrogen components, enzyme activities, and yields were investigated. Seven treatments were set up in this study, including no $\mathrm{N}$ fertilizer (CK), 100\% conventional urea (U), $100 \%$ controlled-release urea $(\mathrm{S}), 30 \%$ controlled-release urea $\left(\mathrm{SU}_{3 / 7}\right), 50 \%$ controlled-release urea $\left(\mathrm{SU}_{5 / 5}\right), 70 \%$ controlled-release urea $\left(\mathrm{SU}_{7 / 3}\right)$ and Sodium Salt of Polyaspartic Acid (PASP)-N. The results showed that mixed CRU-N and urea increased yields and net benefits compared with conventional urea at the same application rate of $\mathrm{N}$, and reduced $\mathrm{N}$ loss. The application of CRU-N at 70\% for maize represented the best overall effects. Compared with $U$ treatment, soil ammonium nitrogen $\left(\mathrm{NH}_{4}-\mathrm{N}\right)$, soil nitrate-nitrogen $\left(\mathrm{NO}_{3}-\mathrm{N}\right)$, and microbial biomass nitrogen (SMB-N) of CRU-N at $70 \%\left(\mathrm{SU}_{7 / 3}\right)$ increased by $35.00 \%, 15.53 \%$, and $25.04 \%$. However, soil nitrate reductase (S-NR) and urease (S-UA) were the best in $\mathrm{SU}_{5 / 5}$ and significantly higher than other treatments. The applications of CRU-N would effectively increase soil N; CRU-N in $50 \%$ proportion can promote the maize root growth and improve the efficient utilization of $\mathrm{N}$ by soil microorganisms. Like the yields $\left(9186.61 \mathrm{~kg} / \mathrm{hm}^{2}\right)$, expertly in the proportion of $70 \% \mathrm{CRU}-\mathrm{N}\left(\mathrm{SU}_{7 / 3}\right)$ plays a vital role in a wheat-maize rotation system, which can potentially be used to improve the yields, nitrogen use efficiency, and net benefit with low $\mathrm{N}$ losses. In conclusion, using CRU-N fertilize effectively improves soil nitrogen, and various ratios of CRU-N can ensure the continuous release the nutrients during the growing period. And among the different proportions of CRU-N, it is optimal in $\mathrm{SU}_{7 / 3}$.

Keywords: controlled-release urea, nitrogen regulation, maize grain yield, soil, reducing, postponing DOI: $10.25165 /$ j.ijabe.20221501.6888
\end{abstract}

Citation: Ji P T, Peng Y J, Cui Y W, Li X L, Tao P J, Zhang Y C. Effects of reducing and postponing controlled-release urea application on soil nitrogen regulation and maize grain yield. Int J Agric \& Biol Eng, 2022; 15(1): 116-123.

\section{Introduction}

Nitrogen is a limiting element for maize growth as well as a crucial factor closely related to maize yield ${ }^{[1]}$. The rotation of winter wheat and summer maize is one of the most critical cropping systems in the north of China, providing more than $52.4 \%$ of wheat and $32.1 \%$ of maize production on $25.1 \%$ of China's arable land ${ }^{[2]}$. Worku et al. ${ }^{[3]}$ believed that maize is well tolerant to fertilizer and more sensitive to nitrogen fertilizer, whose

\section{Received date: 2021-07-12 Accepted date: 2021-12-09}

Biographies: Pengtao Ji, PhD, Research Associate, research interest: crop production system regulation engineering, Email: Jipengtao1987@126.com; Yujuan Peng, Master, Research Associate, research interest: crop production system regulation engineering, Email: 929360008@qq.com; Yongwei Cui, PhD, Associate Professor, research interest: rural revitalization and modern agriculture, Email: cuiyongwei@126.com; Xiangling Li, PhD, Lecturer, research interest: crop production system regulation engineering, Email: ncqyfz2008@126.com; Peijun Tao, PhD, Professor, research interest: crop cultivation and agricultural extension., Email: taopeijun@sina.com.

*Corresponding author: Yuechen Zhang, $\mathrm{PhD}$, Professor, research interest: crop production system regulation engineering. College of Agronomy, Hebei Agricultural University/State Key Laboratory of North China Crop Improvement and Regulation, Baoding 071001, Hebei, China. Tel: +86-13503223858, Email: Zhangyc1964@126.com. application plays a major role in increasing crop yields. With rising crop yields, using highly efficient fertilizers has become one of the key measures to reduce environmental pollution caused by excessive fertilization ${ }^{[4]}$. Urea accounts for approximately $73.4 \%$ of all $\mathrm{N}$ fertilizers applied to maize, and its application can raise global maize yields by $30 \%-50 \%{ }^{[5,6]}$.

Many effective $\mathrm{N}$ management practices have improved nitrogen use efficiency (NUE) ${ }^{[7]}$. In China, controlled-release nitrogen fertilizer (CRU-N) has become the major trend in fertilizer application because of its excellent slow-release performance ${ }^{[8]}$. With increasingly mature technology and decreasing costs, the quality of CRU-N has been dramatically improved in recent years ${ }^{[9,10]}$. The benefits of controlled-release urea (CRU-N) are designed to release $\mathrm{N}$ based on $\mathrm{N}$ requirements for maize to cut down on nitrogen and reduce undesirable environmental pollution without decreasing crop yields ${ }^{[11,12]}$. Precisely, CRU-N fits with $\mathrm{N}$ requirements formalize because of its slow N-released behavior. Not only slowing down the release of nutrients but also improving the nitrogen use efficiency, CRU-N makes the nutrient release be in synch with the nutrient requirements for maize as much as possible ${ }^{[13]}$. It was reported that CRU-N could effectively reduce nitrogen loss, improve nitrogen use efficiency and maintain nitrogen balance throughout the growing process of maize ${ }^{[14]}$. 
Moreover, it can effectively decrease $\mathrm{N}$ leaching in soil and reduce $\mathrm{N}_{2} \mathrm{O}, \mathrm{NH}_{3}$ emissions, thus reducing the required amount of $\mathrm{N}$ application to maintain crop yield ${ }^{[15,16]}$. It was found that CRU-N uses efficiency, tracking by ${ }^{15} \mathrm{~N}$ isotope tracer technique, increased by $7.7 \%$ compared with the conventional urea. However, due to the high cost of CRU-N and the slow release rate of nutrients in the early stage, it is easy to result in "The green" issue after suffering from a nitrogen deficiency.

Fertilizer type and fertilization time that under " $4 \mathrm{R}$ " (right source, right rate, right time, and right place) conditions can be achieved using CRU-N. Still, a reasonable fertilization rate is the basis of precision nutrient management ${ }^{[17,18]}$. The appropriate proportion of CRU-N determined the optimal fertilizing strategy. Long-term field experiments with various proportions of CRU-N have been conducted to identify CRU-N effects ${ }^{[9]}$. Determining a reasonable CRU-N proportion requires a scientific and flexible fertilizing recommendation ${ }^{[13]}$. Previous studies have focused on the $\mathrm{N}$ release patterns of CRU-N that are in synch with crop $\mathrm{N}$ requirements, the reduction of $\mathrm{N}$ leaching, and the emission of $\mathrm{N}_{2} \mathrm{O}$, all of which are helpful to the increases of $\mathrm{N}$ uptake, maize biomass, and economic benefits ${ }^{[16]}$. However, the mechanism of how CRU-N affects soil nitrogen to increase crop yields has not been fully elucidated, especially the effects on soil enzyme activities, the grain number per era and 100-grain weight, and the influence of these changes on the maize $\mathrm{N}$ uptake and yield ${ }^{[18,19]}$. Therefore, in this study, the combination of using CRU-N and reducing fertilizer was adopted to improve the shortages above. The aim is to determine the appropriate proportion of application to meet the nutritional needs of crop growth at an early stage and finally to reduce economic costs.

The objective of this study was to compare the effects of blended CRU-N treatments (mixture of hybrid fertilizer technology) and conventional urea fertilizer treatments on soil nitrogen (ammonium nitrogen, nitrate-nitrogen, total nitrogen, and microbial biomass nitrogen), enzyme activities (nitrate reductase and urease), plant nitrogen (total nitrogen of leaf, stem, and seed) and characteristics of maize (grain yield, ear grain, grain number, and hundred-grain weight)

\section{Materials and methods}

\subsection{Experimental site and materials}

Field experiments were conducted in a rotation of winter-wheat and summer-maize in Xinji Experimental Station, Hebei Agricultural University $\left(43^{\circ} 31^{\prime} \mathrm{N}, 124^{\circ} 48^{\prime} \mathrm{E}\right)$, Xinji City, Hebei Province, China. The annual air temperature and rainfall averages from 1980 to 2010 were $13.8^{\circ} \mathrm{C}$ and $516.4 \mathrm{~mm}$, respectively. The field's soil was classified as clay loam by Chinese Soil Taxonomy (CST2001). The experiments were conducted during the maize growing seasons (June to October) in 2018 and 2020. The soil chemical properties at the beginning of the experiment were as follows: soil organic matter (SOC: $1.86 \mathrm{~g} / \mathrm{kg}$ ), total nitrogen (TN: $0.84 \mathrm{~g} / \mathrm{kg}$ ), available $\mathrm{K}$ (AK: $116.5 \mathrm{mg} / \mathrm{kg}$ ), and available P (AP: $8.92 \mathrm{mg} / \mathrm{kg}$ ). The soil texture was the silt loam with $124.9 \mathrm{~g} / \mathrm{kg}$ sand, $734.8 \mathrm{~g} / \mathrm{kg}$ silt, and $140.3 \mathrm{~g} / \mathrm{kg}$ clay based on the method of Miller and Miller ${ }^{[20]}$. The fertilizers used for this study during three years were polymer and sulfur-coated urea (PSCU, 35\% N, 3-month release), polymer-coated urea (PCU, 43\% N, 3-month release, conventional urea $(46 \% \mathrm{~N})$, super-phosphate $\left(18 \% \mathrm{P}_{2} \mathrm{O}_{5}\right)$ and potassium sulfate $\left(50 \% \mathrm{~K}_{2} \mathrm{O}\right)$. These fertilizer materials were obtained from the National Engineering Research Center for Slow/Controlled-Release
Fertilizer of Hebei Agricultural University.

\subsection{Experimental design and field management}

The factorial experiment consisted of two types of fertilizers: conventional urea fertilizer (U) and the combination of controlled-release urea fertilizer (CRU-N) and conventional urea in the proportion of $30 \%\left(\mathrm{SU}_{3 / 7}\right), 50 \%\left(\mathrm{SU}_{5 / 5}\right), 70 \%\left(\mathrm{SU}_{7 / 3}\right)$ and $100 \%$ (S). Three $\mathrm{N}$ application rates $\left(150 \mathrm{~kg} / \mathrm{hm}^{2}, 300 \mathrm{~kg} / \mathrm{hm}^{2}\right.$, and $450 \mathrm{~kg} / \mathrm{hm}^{2}$ ) for each type of fertilizers went with seven treatments $\left(\mathrm{S}, \mathrm{U}, \mathrm{SU}_{3 / 7}, \mathrm{SU}_{5 / 5}, \mathrm{SU}_{7 / 3}\right.$, and PASP-N), a control treatment (CK) without $\mathrm{N}$ fertilizer. Each experiment was performed in three replicates. Each treatment plot was $8 \mathrm{~m}$ long and $5 \mathrm{~m}$ wide and random permutation. Summer maize was seeded at $5 \mathrm{~cm}$ depth with a $20 \mathrm{~cm}$ plant-to-plant spacing and $60 \mathrm{~cm}$ row-to-row spacing. There were 4 rows of maize in each plot. The total plant density of maize was 675000 plants $/ \mathrm{hm}^{2}$. Fertilizer placement depth was $10-15 \mathrm{~cm}$, and it was $10 \mathrm{~cm}$ away from seeds planted in a row. The ratio of maize seed rows to fertilizer application rows was $1: 1$ in each treatment plot. $U$ treatment was applied as a one-time application of basal fertilizer. For CRU-N treatment, the contents of $\mathrm{N}, \mathrm{P}_{2} \mathrm{O}_{5}$, and $\mathrm{K}_{2} \mathrm{O}$ in nitrogen fertilizer were $43 \%, 5 \%$, and $5 \%$, respectively. Each treatment's phosphorus and potassium fertilizers were calculated as $\mathrm{P}_{2} \mathrm{O}_{5}$ and $\mathrm{K}_{2} \mathrm{O}$, and the application amount was $90 \mathrm{~kg} / \mathrm{hm}^{2}$. All treatments received $90 \mathrm{~kg} / \mathrm{hm}^{2}\left(\mathrm{P}_{2} \mathrm{O}_{5}\right)$ as super-phosphate and $300 \mathrm{~kg} / \mathrm{hm}^{2}\left(\mathrm{~K}_{2} \mathrm{O}\right)$ as potassium sulfate at the time of planting. Xianyu No. $688\left(\mathrm{XY}_{688}\right)$, a maize cultivar with high nitrogen efficiency, was planted in June and harvested in October. Traditional management practices were applied to maize planting in experimental areas except for $\mathrm{N}$ fertilizer.

\subsection{Sampling and chemical analyses}

\subsubsection{Soil sample collection and nitrogen index analysis}

According to the maize growth periods, it was roughly divided into five stages, seeding stage (June 22th), jointing stage (July 15th), flare opening stage (August 1st), flowering stage (September 1st), and mature stage (October 1st). Three vital times for soil nitrogen research were chosen, the jointing stage, growth stage, and mature stage. Soil samples were collected for two different purposes, just 0-10 cm was collected during each stage of growth. The other soil samples were collected before the experiment. To determine the distribution of nitrogen and enzyme activities as soil depth increases. The sample depth ranged from 0 to $60 \mathrm{~cm}$, and was divided into 6 layers were $0-10 \mathrm{~cm}, 10-20 \mathrm{~cm}, 20-30 \mathrm{~cm}$, $30-40 \mathrm{~cm}, 40-50 \mathrm{~cm}$, and $50-60 \mathrm{~cm}$. A non-equidistant irregular grid method was used to collect samples, and there were 6-7 replications for each site using a $20 \mathrm{~cm} \times 5 \mathrm{~cm}$ soil auger. Each fresh soil was thoroughly mixed $(1.5-2.0 \mathrm{~kg})$ and placed into a plastic bag for laboratory analysis. All samples were air-dried and polished by passing through a $0.25-\mathrm{mm}$ sieve.

The total soil nitrogen was measured using the micro-Kjeldahl $\operatorname{method}^{[21]}$. The ammonium and nitrate-nitrogen were determined by $\mathrm{KCl}$ digestion and assessed by Flow Injection Analysis (FIA), Segmented Flow Analysis (SFA), and Continuous Flow Analysis (CFA)-Automated Chemistry Analyzer. For soil enzyme activity, Nitrate reductase (NR) activity was measured by the method reported by Sinha et al. ${ }^{[22]}$ Urease activity was measured by releasing ammonium after soil incubation with urea as the substrate ${ }^{[23]}$.

2.3.2 Plant sample collection and total nitrogen analysis

Three plants from each plot were cut from the ground level and separated into leaves, stems, and grain. All tissue samples were dried at $105^{\circ} \mathrm{C}$ for $30 \mathrm{~min}$ to deactivate enzymes and then placed at $75^{\circ} \mathrm{C}$ until weight remained constant. The samples were weighed 
for dry weight, ground, and sieved through $0.12 \mathrm{~mm} \mathrm{mesh}{ }^{[24]}$. The total $\mathrm{N}$ contents in leaves and stems of these samples were determined using Vario Macro Cube (Elementar, Germany). The harvested grain from seeds was dried until kept constant $\left(60^{\circ} \mathrm{C}\right.$ for $72 \mathrm{~h}$ ). The grain samples were ground and then digested with $\mathrm{H}_{2} \mathrm{SO}_{4}-\mathrm{H}_{2} \mathrm{O}_{2}$ using the Kjeldahl method.

\subsubsection{Grain yield}

After the maize was mature, the yield of each plot was calculated by harvesting, the number of grains per ear, the weight of 100 grains per ear and the yield were investigated. When maize became ripe, three rows of plants in the middle of each plot were collected to determine maize yield. The maize yield was performed in three replicates, which correspond with each treatment replicates. Another five plants were collected from each plot and separated into straw and grain to determine the harvest index.

\subsection{Statistical analysis}

A variety of statistical analyses were conducted to identify the effects of growing period and nitrogen fertilization tactics on the soil total nitrogen, ammonium nitrogen, nitrate-nitrogen, microbial biomass nitrogen. A one-way analysis of variance (ANOVA) with the growing period, soil layer, and nitrogen fertilization tactics as the main factors were employed to test the significance of the mean difference; the level set for a significant difference was $p<0.05$. A univariate procedure was used to examine the normality of the distribution of the observed data before conducting the ANOVA analysis. When the ANOVA test indicated a significant effect at $p<0.05$, the means of each soil variable for each classification factor were assessed using the Duncan multiple-range procedure. Statistical analyses were performed with R software v3.4.2.

\section{Results and discussion}

\subsection{Soil nitrogen patterns}

The average total nitrogen decreased gradually with the soil depth increasing: $0.86,0.74,0.63,0.51,0.47$ and $0.42 \mathrm{~g} / \mathrm{kg}$ in the 0-10 cm, $10-20 \mathrm{~cm}, 20-30 \mathrm{~cm}, 30-40 \mathrm{~cm}, 40-50 \mathrm{~cm}$, and $50-60 \mathrm{~cm}$ soil layers, respectively. However, the vertical distribution of soil nitrate-nitrogen $\left(\mathrm{NO}_{3}{ }^{-} \mathrm{N}\right)$ and ammonium nitrogen $\left(\mathrm{NH}_{4}{ }^{-} \mathrm{-N}\right)$ did not show any changes. Soil nitrate-nitrogen $\left(\mathrm{NO}_{3}^{-}-\mathrm{N}\right)$ and ammonium nitrogen $\left(\mathrm{NH}_{4}^{-}-\mathrm{N}\right)$ in the $20-30 \mathrm{~cm}$ layer were the highest $(6.89$ and $4.69 \mathrm{mg} / \mathrm{kg})$. And the concentration of soil microbial biomass nitrogen (SMB-N) in the $10-20 \mathrm{~cm}$ layer was the greatest $(58.27 \mathrm{mg} / \mathrm{kg})$.

The coefficient of variation (CV) classification of soil nitrogen patterns was used to indicate the extent of their variability. A CV value $\leq 15 \%$ indicates low variability, $16 \% \leq \mathrm{CV} \leq 35 \%$ indicates moderate variability, and a $\mathrm{CV}$ value $\geq 36 \%$ indicates high variability ${ }^{[25]}$. As shown in Table 2, the variable coefficients for total $\mathrm{N}, \mathrm{NH}_{4}{ }^{-}-\mathrm{N}, \mathrm{NO}_{3}{ }^{-}-\mathrm{N}$, and SMB-N were $40.95 \%-45.25 \%$, $62.33 \%-70.12 \%$, $\quad 61.23 \%-72.36 \%$, and $52.36 \%-64.23 \%$, respectively. All soil nitrogen patterns were classified as high variability, and the mean total $\mathrm{N}$ decreased as the soil depth increased; its standard deviation also declined over the soil profile. The variable coefficient values for six layers were $45.12 \%, 45.25 \%$, $44.90 \%, 42.12 \%, 41.58 \%$ and $40.95 \%$, showing no significant differences. As the soil depth increased, changes in the total nitrogen variable coefficient were influenced by the means and standard deviations between the layers $0-10 \mathrm{~cm}$ and $50-60 \mathrm{~cm}$. It is significant in soil $\mathrm{NH}_{4}^{-}-\mathrm{N}$ and $\mathrm{NO}_{3}^{-}-\mathrm{N}$.
Table 1 Descriptive analysis of soil nitrogen patterns

\begin{tabular}{|c|c|c|c|c|c|c|}
\hline Index & Soil depth/cm & Mean & SD & Min & Max & $\mathrm{CV} / \%$ \\
\hline \multirow{6}{*}{$\underset{\mathrm{TN} \cdot \mathrm{kg}^{-1}}{\mathrm{TN}}$} & $0-10$ & 0.86 & 0.38 & 0.24 & 2.16 & 45.12 \\
\hline & $10-20$ & 0.74 & 0.31 & 0.18 & 1.78 & 45.25 \\
\hline & $20-30$ & 0.63 & 0.28 & 0.15 & 1.38 & 44.90 \\
\hline & $30-40$ & 0.51 & 0.25 & 0.14 & 1.23 & 42.12 \\
\hline & $40-50$ & 0.47 & 0.18 & 0.12 & 1.18 & 41.58 \\
\hline & $50-60$ & 0.42 & 0.15 & 0.09 & 1.02 & 40.95 \\
\hline \multirow{6}{*}{$\begin{array}{l}\mathrm{NO}_{3}{ }^{-}-\mathrm{N} \\
/ \mathrm{mg}^{-} \mathrm{kg}^{-1}\end{array}$} & $0-10$ & 5.78 & 2.12 & 3.22 & 8.24 & 62.33 \\
\hline & $10-20$ & 6.12 & 2.36 & 2.08 & 10.26 & 68.26 \\
\hline & $20-30$ & 6.89 & 3.08 & 1.24 & 11.12 & 70.12 \\
\hline & $30-40$ & 5.41 & 4.23 & 2.89 & 7.23 & 65.34 \\
\hline & $40-50$ & 4.92 & 2.12 & 2.02 & 8.11 & 63.12 \\
\hline & $50-60$ & 4.28 & 1.23 & 2.12 & 8.23 & 63.34 \\
\hline \multirow{6}{*}{$\begin{array}{l}\mathrm{NH}_{4}{ }^{+}-\mathrm{N} \\
/ \mathrm{mg}^{-} \mathrm{kg}^{-1}\end{array}$} & $0-10$ & 5.12 & 2.36 & 3.56 & 8.36 & 72.12 \\
\hline & $10-20$ & 3.85 & 1.15 & 1.25 & 5.98 & 69.23 \\
\hline & $20-30$ & 4.69 & 2.24 & 2.45 & 9.88 & 66.36 \\
\hline & $30-40$ & 4.25 & 1.89 & 2.46 & 8.24 & 68.12 \\
\hline & $40-50$ & 4.02 & 2.12 & 1.98 & 8.12 & 72.36 \\
\hline & $50-60$ & 3.68 & 1.65 & 1.31 & 6.77 & 61.23 \\
\hline \multirow{6}{*}{ 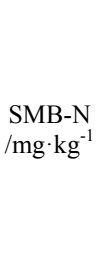 } & $0-10$ & 46.88 & 12.28 & 30.55 & 77.23 & 64.23 \\
\hline & $10-20$ & 58.27 & 16.39 & 32.11 & 75.23 & 52.36 \\
\hline & $20-30$ & 50.35 & 21.56 & 19.35 & 82.58 & 61.11 \\
\hline & $30-40$ & 48.36 & 17.89 & 20.69 & 76.12 & 58.36 \\
\hline & $40-50$ & 43.23 & 14.36 & 18.99 & 68.32 & 56.85 \\
\hline & $50-60$ & 40.88 & 12.85 & 21.36 & 62.36 & 52.36 \\
\hline
\end{tabular}

3.2 Soil nitrogen patterns under different nitrogen fertilization

Urea is converted to ammonium carbonate through urease and further transformed to $\mathrm{NH}_{4}-\mathrm{N}$ and $\mathrm{NO}_{3}-\mathrm{N}$, both of which can be absorbed and utilized by crops. Infertile soil, conventional urea could be completely hydrolyzed within 4 da but only about $20 \%$ can be absorbed by soil colloid ${ }^{[26]}$. Nutrient requirements are increasing along with maize growing. However, the conventional urea $(\mathrm{U})$ cannot be retained throughout the whole growing season to meet crop needs for N. Therefore, it is time-consuming and laborious to apply $\mathrm{N}$ fertilizer during crop growth. Although the release of CRU-N is slow, the stable release can meet nitrogen requirements for crops ${ }^{[27]}$. The problem is that yields go through limited nitrogen supply at the early development stage. $U$ and CRU-N were mixed at different ratios and studied the differences of those nitrogen fertilizers, the effects on soil $\mathrm{N}$ components, enzyme activities, maize total $\mathrm{N}$ and yields during the growth process. To determine the appropriate type of fertilizer for achieving the requirements of maize grow in the current season and the nutrient accumulation in the next season. The ultimate purpose is to improve nitrogen use efficiency.

\subsubsection{Soil total nitrogen}

As shown in Figure 1, the effects of controlled-release nitrogen fertilizer on soil total nitrogen (TN) were different during the main growth stages. The concentrations of $\mathrm{TN}$ in other fertilization treatments were significantly lower than that in CK treatment. And soil $\mathrm{TN}$ in $\mathrm{U}, \mathrm{SU}_{3 / 7}$, and $\mathrm{SU}_{7 / 3}$ treatments differed among jointing, growing, and mature periods. In the jointing period, soil $\mathrm{TN}$ was the greatest under $U$ treatment, and there was a statistically significant difference from other treatments. The concentration of $\mathrm{TN}$ ranged from 0.42 to $1.13 \mathrm{~g} / \mathrm{kg}$. In the growing period, soil $\mathrm{TN}$ was the highest under treatment of $\mathrm{S}$, and there was no statistical 
significance with $\mathrm{SU}_{7 / 3}$ treatments. The concentration of $\mathrm{TN}$ ranged from 0.39 to $1.15 \mathrm{~g} / \mathrm{kg}$. The highest value appeared in the $\mathrm{S}$ treatment in the mature stage, and there was statistical significance among the other treatments. The concentration of soil TN increased by $71.22 \%$ compared to CK treatment.

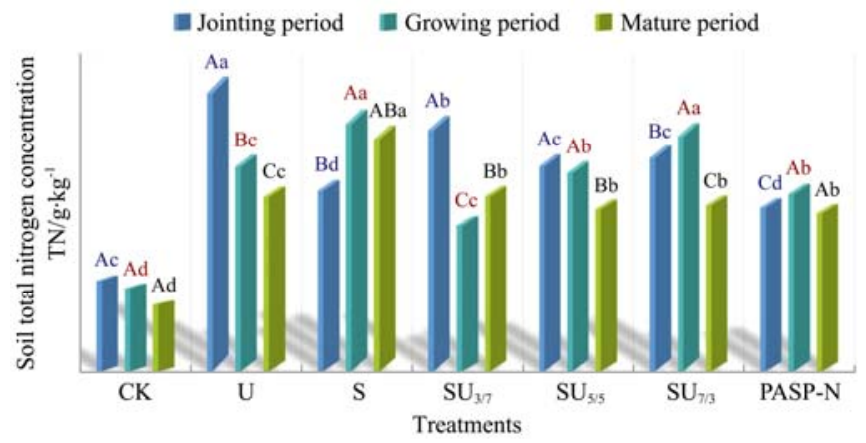

Note: CK: No $\mathrm{N}$ fertilizer (CK); U: $100 \%$ conventional urea; S: $100 \%$ controlled-release urea; $\mathrm{SU}_{3 / 7}: \quad 30 \%$ controlled-release urea; $\mathrm{SU}_{5 / 5}: 50 \%$ controlled-release urea; $\mathrm{SU}_{7 / 3}: 70 \%$ controlled-release urea; PASP-N: Sodium Salt of Polyaspartic Acid-N. Values are presented as the means of three replicates \pm standard (std.) Uppercase letters indicate a significant difference among the different growth stages $(p<0.05)$. Lowercase letters indicate significant differences among the different fertilization treatments $(p<0.05)$. The following is the same.

Figure 1 Changes of soil total nitrogen in the different growth stages

\subsubsection{Soil ammonium nitrogen $\left(\mathrm{NH}_{4}^{-}-\mathrm{N}\right)$}

As shown in Figure 2, the effects of controlled-release nitrogen fertilizer on soil ammonium nitrogen $\left(\mathrm{NH}_{4}^{-}-\mathrm{N}\right)$ were varied. The concentrations of $\mathrm{NH}_{4}^{-}-\mathrm{N}$ in different fertilization treatments were remarkably lower than that in $\mathrm{CK}$ treatment. And soil $\mathrm{NH}_{4}^{-}-\mathrm{N}$ in $\mathrm{U}, \mathrm{SU}_{7 / 3}$, and PASP-N treatments were significantly different among jointing, growing and mature periods. In the jointing period, soil $\mathrm{NH}_{4}^{-}-\mathrm{N}$ under $\mathrm{U}$ the treatment was the greatest, and there was no statistical significance among $\mathrm{U}, \mathrm{SU}_{3 / 7}$, and $\mathrm{SU}_{5 / 5}$ treatments. The concentration of $\mathrm{NH}_{4}^{-}-\mathrm{N}$ ranged from 4.23 to $7.98 \mathrm{mg} / \mathrm{kg}$. In the growing period, soil $\mathrm{NH}_{4}^{-}-\mathrm{N}$ in the treatment of $\mathrm{SU}_{3 / 7}$ was the highest, and there was no statistical significance with S and PASP-N treatments. But it was $97.16 \%$ higher than CK treatment. The concentration of $\mathrm{NH}_{4}^{-}-\mathrm{N}$ ranged from 3.87 to $7.63 \mathrm{mg} / \mathrm{kg}$. The highest value appeared in $\mathrm{S}$ treatment in the mature stage, and there was statistical significance among other treatments. The soil $\mathrm{NH}_{4}{ }^{-} \mathrm{N}$ concentration increased by $165 \%$ compared to $\mathrm{CK}$ treatment, and compared with $\mathrm{U}$ treatment, it also increased by $35 \%$.

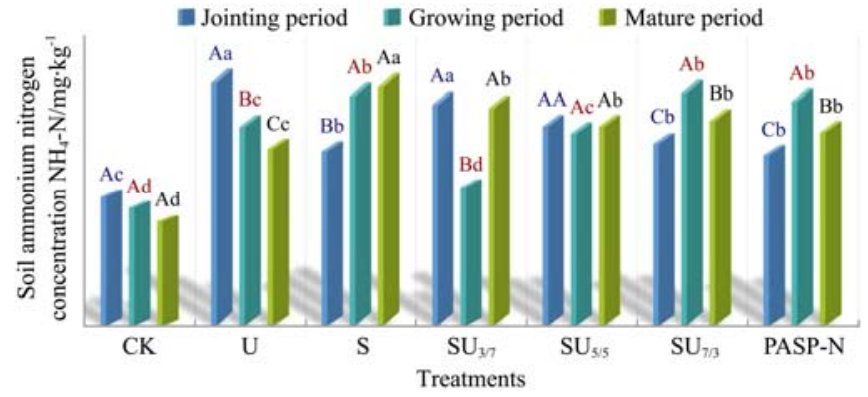

Figure 2 Changes of soil $\mathrm{NH}_{4}-\mathrm{N}$ in the different growth stages

\subsubsection{Soil nitrate-nitrogen $\left(\mathrm{NO}_{3}{ }^{+}-\mathrm{N}\right)$}

As shown in Figure 3, soil nitrate-nitrogen $\left(\mathrm{NO}_{3}-\mathrm{N}\right)$ changed obviously under different fertilization treatments. The descending order of the concentration of $\mathrm{NO}_{3}-\mathrm{N}$ in different treatments was Jointing period, Growing period, Mature period. In addition, there was no statistical significance between $\mathrm{CK}$, PASP-N, and the other treatments. In the jointing period, soil $\mathrm{NO}_{3}-\mathrm{N}$ under $\mathrm{SU}_{7 / 3}$ treatment was the greatest, and the value was $20.55 \mathrm{mg} / \mathrm{kg}$. It was significantly different from other treatments, which was $39.85 \%$ higher than that under CK treatment and $7.83 \%$ higher than that under $\mathrm{U}$ treatment. In the growing period, soil $\mathrm{NH}_{4}^{-}-\mathrm{N}$ in treatment of $U$ was the highest, and the value was $16.54 \mathrm{mg} / \mathrm{kg}$. There was no statistical significance among $\mathrm{U}, \mathrm{SU}_{3 / 7}$, and $\mathrm{SU}_{5 / 5}$ treatments. The highest value appeared in PASP-N treatment in the mature stage, and there was statistical significance among other treatments. It was $31.29 \%$ higher than CK treatment and $15.53 \%$ higher than $\mathrm{U}$ treatment.

Compared with $\mathrm{N}$-fertilizer free treatment (CK), nitrogen fertilizer application could remarkably increase the concentrations of $\mathrm{TN}, \mathrm{NO}_{3}-\mathrm{N}$, and $\mathrm{NH}_{4}-\mathrm{N}$, among which $\mathrm{TN}$ and $\mathrm{NH}_{4}-\mathrm{N}$ were most strong ${ }^{[28,29]}$. In the joint period, there was no statistically significant difference in various proportions of CRU-N, except $\mathrm{CK}$, $\mathrm{S}$, and $\mathrm{SU}_{3 / 7}$ treatments. The nitrogen compounds under $\mathrm{SU}_{3 / 7}$ treatments in different growth stages were unstable. Available nitrogen during the growing period was too low to affect maize growth. However, the trend was different from that in the growing time. Although the concentrations of $\mathrm{TN}$ and $\mathrm{NH}_{4}-\mathrm{N}$ under $\mathrm{S}$ treatment were higher, the difference among the controlled-release nitrogen fertilizer (CRU-N) was not statistically significant. The ascending order of the ranking of $\mathrm{TN}$ and $\mathrm{NH}_{4}-\mathrm{N}$ under various proportions of CRU-N was $\mathrm{SU}_{3 / 7}, \mathrm{SU}_{5 / 5}, \mathrm{SU}_{7 / 3}$. Those results indicated that the decreases of the conventional urea (U) and the increases of the proportion of $100 \%$ controlled-release urea $(\mathrm{S})$ would benefit nitrogen accumulation. $30 \%$ traditional urea in $\mathrm{SU}_{7 / 3}$ was enough to solve the problem of nitrogen deficiency in soil ${ }^{[12,30]}$.

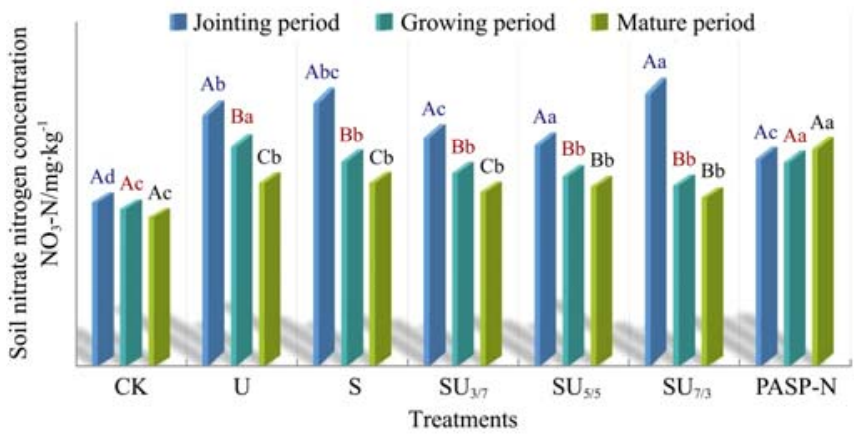

Figure 3 Changes of soil nitrate-nitrogen in the different growth stages

\subsubsection{Soil microbial biomass nitrogen (SMB-N)}

As shown in Figure 4, during the growth stages, soil microbial biomass nitrogen (SMB-N) changed obviously under different fertilization treatments. The descending order of the concentration of SMB-N in different treatments was the jointing period, growing period, mature period. Soil SMB-N in U, S, $\mathrm{SU}_{3 / 7}$, and $\mathrm{SU}_{7 / 3}$ treatments were significantly different among jointing, growing and mature periods. In the jointing period, SMB-N under S treatment was the greatest, and the value was $37.74 \mathrm{mg} / \mathrm{kg}$. It was significantly different from other treatments, $55.55 \%$ higher than that under CK treatment and $25.04 \%$ higher than that under $U$ treatment. In the growing period and mature stage, SMB-N in treatment of $\mathrm{SU}_{3 / 7}$ was the lowest, $18.00 \mathrm{mg} / \mathrm{kg}$ and $14.81 \mathrm{mg} / \mathrm{kg}$, respectively. There was no statistical significance among $\mathrm{U}, \mathrm{SU}_{5 / 5}, \mathrm{SU}_{7 / 3}$, and PASP-N treatments. And there was statistical significance among other treatments. In the mature period, although the concentrations of soil $\mathrm{TN}, \mathrm{NO}_{3}-\mathrm{N}$, and $\mathrm{NH}_{4}-\mathrm{N}$ were highest under the $\mathrm{S}$ treatment, the CRU-N with 
various proportions were significantly higher than those under the U treatment. They were also kept at a high level with PASP-N, which means CRU-N can release enough $\mathrm{N}$ to ensure the normal growth of maize during growing and mature periods. Soil microbial biomass nitrogen (SMB-N) is one of the indicators of nitrogen utilization. The concentration of SMB-N under $\mathrm{S}$ treatment was the highest and significantly higher than that under $\mathrm{SU}_{3 / 7}$ treatment. The treatment of CRU-N improved the efficacy of nitrogen fertilizer via high-efficient utilization by microorganisms ${ }^{[31]}$. However, the concentration of SMB-N under $\mathrm{SU}_{5 / 5}$ treatment was significantly lower than that under other treatments. The rapid utilization of $U$ treatment would affect the sustainable utilization of $\mathrm{N}$ by soil microorganisms. At the same time, there was a significantly negative correlation among SMB-N, $\mathrm{NO}_{3}-\mathrm{N}$, and $\mathrm{NH}_{4}-\mathrm{N}$, which means when the concentration of $\mathrm{NO}_{3}-\mathrm{N}$ and $\mathrm{NH}_{4}-\mathrm{N}$ becomes high, part of $\mathrm{N}$ may convert into SMB-N. On the contrary, when available $\mathrm{N}$ is deficient, SMB-N can be converted into active components used by maize ${ }^{[32-34]}$.

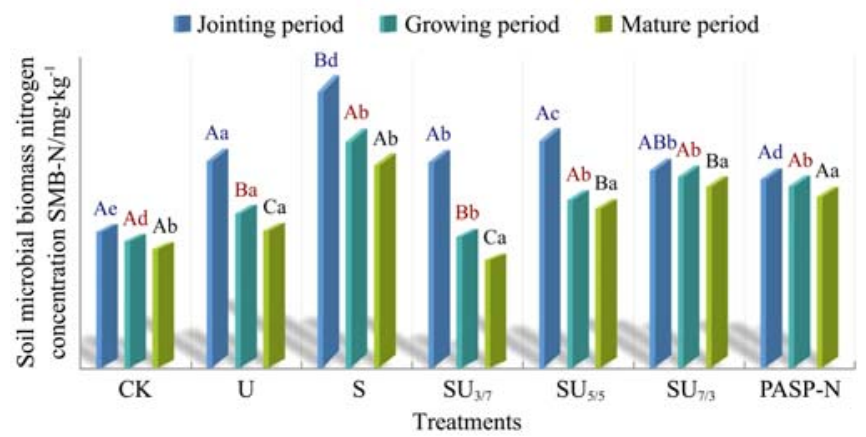

Figure 4 Changes of soil microbial biomass nitrogen in the different growth stages

3.3 Soil enzyme activity under different nitrogen fertilization 3.3.1 Soil nitrate reductase (S-NR)

As shown in Figure 5, soil nitrate reductase (S-NR) changed obviously under different fertilization treatments. The concentrations of S-NR in different fertilization treatments were significantly lower than that in CK treatment. And soil S-NR in U, $\mathrm{S}, \mathrm{SU}_{3 / 7}$, and $\mathrm{SU}_{5 / 5}$ treatments were significantly different among jointing, growing and mature periods. In the jointing and mature period, soil S-NR under $\mathrm{SU}_{5 / 5}$ treatment was the greatest, the value was $220.76 \mu \mathrm{g} / \mathrm{g}$. In the growing period, soil S-NR under $\mathrm{SU}_{5 / 5}$ treatment was the greatest, the value was $400.92 \mu \mathrm{g} / \mathrm{g}$. It was significantly different from other treatments, which was $87.43 \%$ higher than that under CK treatment and $87.28 \%$ higher than that under $\mathrm{SU}_{3 / 7}$ treatment.

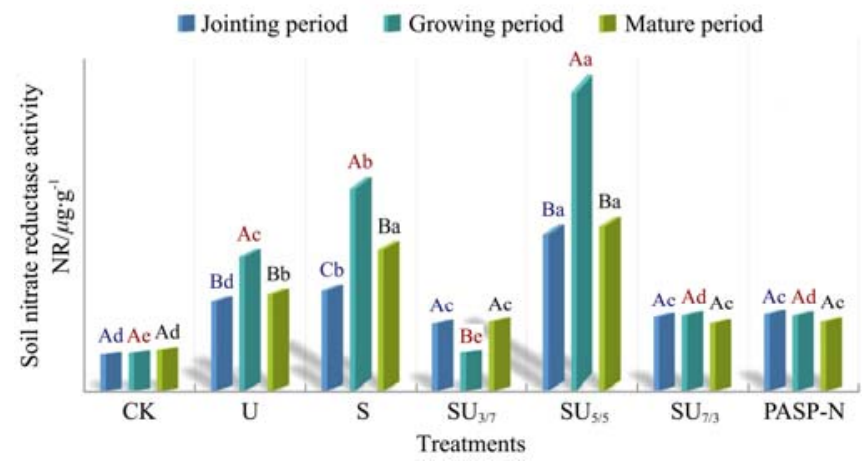

Figure 5 Changes of S-NR in the different growth stages

3.3.2 Soil urease (S-UA)

As shown in Figure 6, soil urease changed obviously under different fertilization treatments. The concentrations of soil urease in different fertilization treatments were significantly lower than $\mathrm{CK}$ treatment. And soil urease in $\mathrm{U}, \mathrm{SU}_{3 / 7}$, and $\mathrm{SU}_{7 / 3}$ treatments was significantly different among jointing, growing, and mature periods. In three growth stages, soil urease with the same trend, and there was the greatest under $\mathrm{SU}_{5 / 5}$ treatment. The values were $72.96 \mu \mathrm{g} / \mathrm{g}, 95.93 \mu \mathrm{g} / \mathrm{g}$, and $90.76 \mu \mathrm{g} / \mathrm{g}$, respectively. It was significantly different from other treatments, $59.98 \%$ higher than that under CK treatment and $57.26 \%$ higher than that under $\mathrm{SU}_{3 / 7}$ treatment.

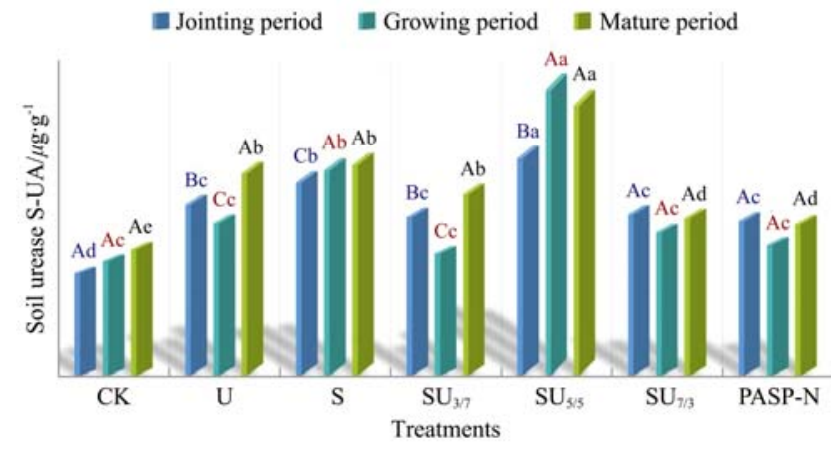

Figure 6 Changes of soil urease in the different growth stages

3.3.3 Relationships between soil enzyme activity and nitrogen compounds

As shown in Table 2, soil total nitrogen (TN) was positively related with nitrate-nitrogen $\left(\mathrm{NH}_{4}-\mathrm{N}\right)$, ammonium nitrogen $\left(\mathrm{NO}_{3}-\mathrm{N}\right)$, microbial biomass nitrogen $(\mathrm{SMB}-\mathrm{N})$, nitrate reductase (S-NR), and urease (S-U). SMB-N was negatively correlated with $\mathrm{NO}_{3}-\mathrm{N}$ and $\mathrm{NH}_{4}-\mathrm{N}$ and positively correlated with $\mathrm{S}-\mathrm{U} . \mathrm{NO}_{3}-\mathrm{N}$ was negatively associated with enzyme activities. Soil enzyme activities were significantly correlated with each other. Soil enzyme activity is one of the important indicators of soil fertility sensitively. Many studies have reported that the CRU-N in different proportions significantly increased soil enzyme activities, especially in soil nitrate reductase (S-NR) and urease representing the transformation of nitrogen ${ }^{[35-37]}$. In this study, soil nitrate reductase (S-NR) and urease under $\mathrm{SU}_{5 / 5}$ treatment was the highest, followed by $\mathrm{S}$, which was significantly higher than other treatments. The trends of soil enzyme activities were different from soil nitrogen patterns during the maize growing season. The descending order was Growing period, Mature period, Joint period. Although CRU-N would effectively increase soil N, CRU-N in $50 \%$ proportion can boost the maize root growth and improve the efficiency of $\mathrm{N}$ utilization by soil microorganisms ${ }^{[13,38]}$. According to the distribution of total $\mathrm{N}$ in leaves and stems, there was no significant difference among $\mathrm{S}, \mathrm{SU}_{7 / 3}$ and PASP-N. Similar to PASP-N, the CRU-N treatment with high proportions can release $\mathrm{N}$ for the growth of maize, although there was no significant difference among milky maturity, ripening and later

Table 2 Relationships between soil enzyme activity and nitrogen compounds

\begin{tabular}{lcccccc}
\hline Compound & $\mathrm{TN}$ & $\mathrm{NH}_{4}-\mathrm{N}$ & $\mathrm{NO}_{3}-\mathrm{N}$ & $\mathrm{SMB}-\mathrm{N}$ & $\mathrm{S}-\mathrm{NR}$ & $\mathrm{S}-\mathrm{U}$ \\
\hline $\mathrm{TN}$ & 1 & & & & & \\
$\mathrm{NH}_{4}-\mathrm{N}$ & 0.482 & 1 & & & & \\
$\mathrm{NO}_{3}-\mathrm{N}$ & 0.201 & 0.563 & 1 & & & \\
$\mathrm{SMB}^{-\mathrm{N}}$ & 4.499 & -0.132 & -0.562 & 1 & & \\
$\mathrm{~S}-\mathrm{NR}$ & 0.722 & 0.323 & -0.006 & $0.896 *$ & 1 & \\
$\mathrm{~S}-\mathrm{U}$ & 0.689 & 0.369 & -0.246 & 0.801 & $0.961 * *$ & 1 \\
\hline Note: ${ }^{*} p<0.05$, & $* * p<0.01$. & $\mathrm{TN}:$ & Total nitrogen; $\mathrm{NH}_{4}-\mathrm{N}:$ Nitrate-nitrogen;
\end{tabular}

$\mathrm{NO}_{3}-\mathrm{N}$ : Ammonium nitrogen; SMB-N: Microbial biomass nitrogen; S-NR Nitrate reductase; S-U: Urease. 
mature stage. However, the yields of $\mathrm{U}, \mathrm{SU}_{3 / 7}$, and $\mathrm{SU}_{5 / 5}$ treatments decreased, while $\mathrm{S}, \mathrm{SU}_{7 / 3}$, and PASP-N treatments increased. The high price of $\mathrm{S}$ and PASP-N treatment would increase the agricultural cost. And it is not economical to use. In addition, field production is uncertain to some degree. The field moisture and temperature will affect all the users, leading to a failure of a double win ideal effect.

\subsection{Effects of different nitrogen fertilization on maize}

\subsubsection{Leaf and straw}

As shown in Figure 7, plant total nitrogen (including maize leaf and straw) changed obviously under different fertilization treatments. In maize leaves, total $\mathrm{N}$ under $\mathrm{SU}_{3 / 7}$ treatment was the greatest, $58.89 \mathrm{~g} / \mathrm{kg}$ in the jointing period. There was no significance with $\mathrm{SU}_{7 / 3}$ and PASP-N treatments but was higher than other treatments. In the growing period, total $\mathrm{N}$ under $\mathrm{SU}_{3 / 7}$ and PASP-N treatments were the greatest, 25.00 and $26.96 \mathrm{~g} / \mathrm{kg}$. The difference was $60.39 \%$ between the highest PASP-N treatment and the lowest value in $\mathrm{S}$ treatment. In the mature period, the highest value was shown in the $U$ treatment, which was $26.97 \mathrm{~g} / \mathrm{kg}$. And there was no significance with PASP-N treatment. In maize straw, total $\mathrm{N}$ under $\mathrm{CK}$ treatment was the greatest, which was $58.89 \mathrm{~g} / \mathrm{kg}$ in the jointing period. There was statistical significance among other treatments. In the growing period, total $\mathrm{N}$ under $\mathrm{CK}$ was the greatest, $30.69 \mathrm{~g} / \mathrm{kg}$. The highest value was shown in the $\mathrm{S}$ treatment in the mature period, which was $24.78 \mathrm{~g} / \mathrm{kg}$.

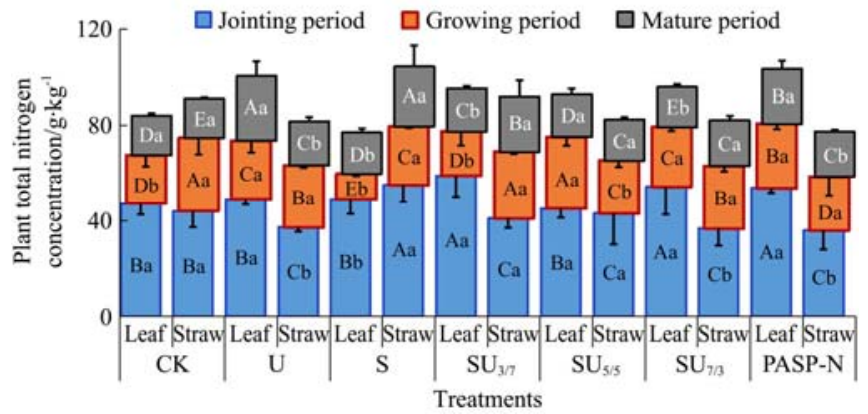

Figure 7 Allocation of plant total nitrogen in different growth

\subsubsection{Seed}

As shown in Figure 8, the total nitrogen of seed changed significantly under different fertilization treatments. Total $\mathrm{N}$ under $\mathrm{U}$ treatment was the greatest, and the value was $14.51 \mathrm{~g} / \mathrm{kg}$ in the milky maturity stage. There was no significance between $\mathrm{S}$, $\mathrm{SU}_{3 / 7}, \mathrm{SU}_{7 / 3}$, and PASP-N treatments, but it was higher than $\mathrm{CK}$ and $\mathrm{SU}_{5 / 5}$. In the ripening stage, there was statistical significance among other treatments. In the later mature stage, total $\mathrm{N}$ under $\mathrm{U}$, $\mathrm{S}, \mathrm{SU}_{3 / 7}, \mathrm{SU}_{5 / 5}, \mathrm{SU}_{7 / 3}$, and PASP-N treatments has no significant difference but were higher than that under $\mathrm{CK}$.

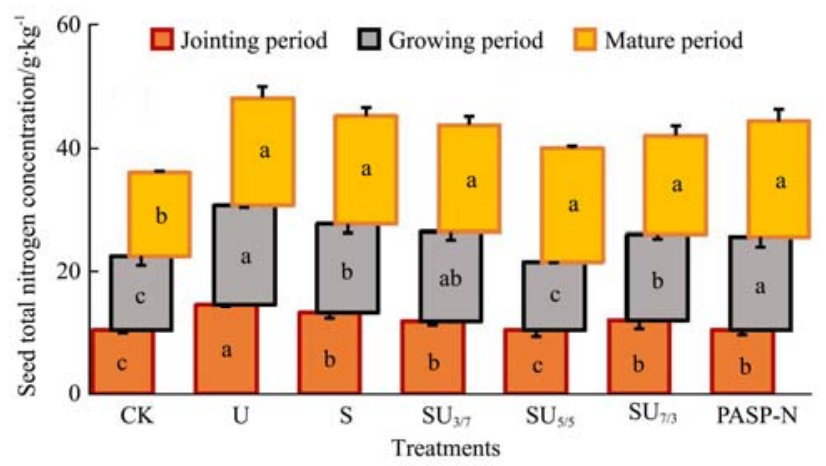

Figure 8 Allocation of seed total nitrogen in a different mature stage
3.5 Effects of controlled-release nitrogen fertilizer on maize yield

3.5.1 Yield

As shown in Table 2, maize yield, ear grain, grain number, and hundred-grain weight were significantly higher than those $\mathrm{N}$ fertilizer treatments. Each treatment was shown from high to low PASP-N, $\mathrm{SU}_{7 / 3}, \mathrm{SU}_{3 / 7}, \mathrm{~S} \mathrm{U}, \mathrm{SU}_{5 / 5}, \mathrm{CK}$. The yield of each treatment with $\mathrm{N}$ fertilizer was markedly higher than that of no $\mathrm{N}$ fertilizer. The increase was between $6.94 \%$ and $15.08 \%$. Maize yield under $\mathrm{SU}_{7 / 3}$ treatment was the greatest, and the value was $9186.61 \mathrm{~kg} / \mathrm{hm}^{2}$. Compared with the U treatment's, the yield increased by $5.83 \%$. Maize yield under treatments of $\mathrm{S}, \mathrm{SU}_{3 / 7}$, and $\mathrm{SU}_{5 / 5}$ was higher than $\mathrm{U}$, but there was no statistical significance among them. Ear grain in $\mathrm{SU}_{5 / 5}, \mathrm{SU}_{7 / 3}$, and PASP-N were higher than other treatments, but there was no statistical significance among them. The numbers of grain among the different $\mathrm{N}$ fertilizer treatments were different. Hundred-grain weight under $\mathrm{SU}_{7 / 3}$ treatment was the highest which was $54494.72 \mathrm{ears} / \mathrm{hm}^{2}$. Compared with the $\mathrm{U}$ treatment, the ear grain increased by $6.04 \%$. Hundred-grain weight under treatments of $\mathrm{S}$, $\mathrm{SU}_{3 / 7}, \mathrm{SU}_{5 / 5}$, and PASP-N has no significant difference.

Basal fertilizer plus topdressing is a traditional fertilization practice in the agricultural industry. However, agriculture currently has encountered the dual pressures of a reduction in the availability of agricultural workers and increase in food requirements ${ }^{[39]}$. Therefore, CRU-N was designed to meet crop nutrient requirements reduce labor demands, and increase crop yields $^{[40]}$. Controlled-release urea has been applied to many crops ${ }^{[41,42]}$. However, the wide use of CRU-N in agriculture is limited by its higher price than that of conventional urea. Therefore, instead of using urea exclusively, the use of mixed CRU-N and urea has been advocated in agricultural industry to gain the benefits of reducing labor costs and increasing crop yields ${ }^{[43,44]}$. Compared with urea, CRU-N continuously increased the yield and net profit by offering N. The maize yield increased by $5.83 \%$. The results suggested that the combination of an optimal fertilization rate and CRU-N can further improve net benefits by increasing profits and decreasing labor costs. The synchronization of $\mathrm{N}$ supply and crop absorption by controlling $\mathrm{N}$ release can maximize $\mathrm{NUE}^{[40,45]}$.

Table 3 Maize yield under different nitrogen fertilizer

\begin{tabular}{ccccc}
\hline Treatments & $\begin{array}{c}\text { Yield } \\
/ \mathrm{kg} \cdot \mathrm{hm}^{-2}\end{array}$ & $\begin{array}{c}\text { Ear grain } \\
\text { /ear } \cdot \mathrm{hm}^{-2}\end{array}$ & $\begin{array}{c}\text { Grain } \\
\text { number }\end{array}$ & $\begin{array}{c}\text { Hundred-grain } \\
\text { weight/g }\end{array}$ \\
\hline $\mathrm{CK}$ & $8117.27 \pm 188.71^{\mathrm{c}}$ & $51389.15 \pm 1272.94^{\mathrm{f}}$ & $433.83 \pm 2.28^{\mathrm{d}}$ & $32.42 \pm 1.27^{\mathrm{d}}$ \\
$\mathrm{U}$ & $8680.40 \pm 340.25^{\mathrm{b}}$ & $52222.48 \pm 1734.73^{\mathrm{e}}$ & $472.90 \pm 6.30^{\mathrm{a}}$ & $35.15 \pm 0.55^{\mathrm{c}}$ \\
$\mathrm{S}$ & $8768.82 \pm 165.81^{\mathrm{b}}$ & $53333.60 \pm 1443.38^{\mathrm{d}}$ & $452.05 \pm 6.78^{\mathrm{b}}$ & $36.39 \pm 0.74^{\mathrm{b}}$ \\
$\mathrm{SU}_{3 / 7}$ & $8716.60 \pm 401.75^{\mathrm{b}}$ & $52500.26 \pm 833.34^{\mathrm{e}}$ & $471.42 \pm 4.47^{\mathrm{a}}$ & $36.23 \pm 2.54^{\mathrm{b}}$ \\
$\mathrm{SU}_{5 / 5}$ & $8899.73 \pm 109.40^{\mathrm{b}}$ & $55278.05 \pm 1272.94^{\mathrm{b}}$ & $443.68 \pm 9.88^{\mathrm{c}}$ & $35.35 \pm 2.49^{\mathrm{c}}$ \\
$\mathrm{SU}_{7 / 3}$ & $9186.61 \pm 479.18^{\mathrm{a}}$ & $54494.72 \pm 962.26^{\mathrm{c}}$ & $455.70 \pm 14.03^{\mathrm{b}}$ & $37.57 \pm 1.62^{\mathrm{a}}$ \\
$\mathrm{PASP} \mathrm{N}$ & $9341.42 \pm 99.55^{\mathrm{a}}$ & $56111.39 \pm 481.13^{\mathrm{a}}$ & $475.59 \pm 11.57^{\mathrm{a}}$ & $35.03 \pm 0.70^{\mathrm{c}}$ \\
\hline
\end{tabular}

\section{Conclusions}

The combination of controlled-release urea fertilizer (CRU-N) could effectively increase soil nitrogen and enzyme activities at each growth stage. It was particularly distinct in the combination of controlled-release urea fertilizer $(\mathrm{CRU}-\mathrm{N})$ under $70 \%\left(\mathrm{SU}_{7 / 3}\right)$. As to yield $\left(9186.61 \mathrm{~kg} / \mathrm{hm}^{2}\right)$, it was also the greatest under the proportion of $70 \%\left(\mathrm{SU}_{7 / 3}\right)$ treatment. Compared with the conventional urea fertilizer (U) treatment, the yield increased $5.83 \%$. Maize yields were not significantly reduced among the 
treatments of $\mathrm{S}, \mathrm{SU}_{3 / 7}$ and $\mathrm{SU}_{5 / 5}$, among which the proportions of the combination of controlled-release urea fertilizer (CRU-N) have been changed. The advantages of the combination of controlled-release urea fertilizer (CRU-N) application are as follows: 1) reduce the times of fertilization and farming; 2) increase soil fertility level and provide nutrients for the next growth stage. In particular, $70 \%\left(\mathrm{SU}_{7 / 3}\right)$ treatment plays an essential role in the wheat-maize rotation system.

\section{Acknowledgements}

This work was financially supported by the National Key Research and Development Program of China (Grant No. 2018YFD0300503). The authors sincerely acknowledge the reviewers for the critical comments on our original manuscript.

\section{[References]}

[1] Tilman D, Cassman K G, Matson P A, Naylor R, Polasky S. Agricultural sustainability and intensive production practices. Nature, 2002; 418(6898): 671-677.

[2] China Agriculture Statistical Report. Editorial Board of Ministry of Agriculture. China Agriculture Press: Beijing, China, 2017; 195p (in Chinese)

[3] Worku M, Nziger M B, Erley G S A, Friesen D, Diallo A O, Horst W J. Nitrogen uptake and utilization in contrasting nitrogen efficient tropical maize hybrids. Crop Science, 2007; 47(2): 519-528.

[4] Li P E, Lu J W, Wang Y. Nitrogen losses use efficiency and productivity of early rice under controlled-release urea. Agr Ecosyst Environ, 2018; 251: 78-87.

[5] Sutton M A, Oenema O, Erisman J M. Too much of a good thing. Nature, 2011; 472 (7342): 159-161.

[6] Homme P H A M. Short-term fertilizer outlook 2016-2017. IFA, 2016; pp.1-3.

[7] Lam S K, Suter H, Bai M, Walker C, Mosier A R, van Grinsven H, et al. Decreasing ammonia loss from an Australian pasture with the use of enhanced efficiency fertilizers. Agriculture Ecosystems \& Environment, 2019; 283: 106553. doi: 10.1016/j.agee.2019.05.012.

[8] Chen Y, Peng J, Wang J, Fu P H, Hou Y, Zhang C D, et al. Crop management based on multi-split topdressing enhances grain yield and nitrogen use efficiency in irrigated rice in China. Field Crops Research, 2015; 184: 50-57.

[9] Ke J, He R, Hou P, Ding C, Ding Y F, Wang S H, et al. Combined controlled-released nitrogen fertilizers and deep placement effects of $\mathrm{N}$ leaching, rice yield and $\mathrm{N}$ recovery in machine-transplanted rice. Agris Ecosyst Environ, 2018; 265: 402-412.

[10] Xiao Y, Peng F, Zhang Y, Wang J, Zhuge Y P, Zhang S S, et al. Effect of bag-controlled release fertilizer on nitrogen loss greenhouse gas emissions and nitrogen applied amount in peach production. J Clean Prod, 2019; 234: 258-274.

[11] Azeem B, KuShaari K, Man Z B, Basit A, Thanh T H. Review on materials \& methods to produce controlled release coated urea fertilizer. Journal Control Release, 2014; 191(1): 11-21.

[12] Zhang W, Liang Z, He X, Wang X W, Shi X J, Zou C Q, et al. The effects of controlled release urea on maize productivity and reactive nitrogen losses: A meta-analysis. Environ Pollut, 2019; 246: 559-565.

[13] Xu C M, Wang D Y, Chen S, Chen L P, Zhang X F. Effects of Aeration on root physiology and nitrogen metabolism in rice. Rice Science, 2013; 20(2): 148-153.

[14] Gao X F, Chen H H, Govaert L, Wang W P, Yang J. Responses of zooplankton body size and community trophic structure to temperature change in a subtropical reservoir. Ecol. Evol, 2019; 22(9): 12544-12555.

[15] Akiyama H, Yan X, Yagi K. Evaluation of effectiveness of enhanced-efficiency fertilizers as mitigation options for $\mathrm{N} 2 \mathrm{O}$ and $\mathrm{NO}$ emissions from agricultural soils: Meta-analysis. Global Change Biology, 2010; 16(6): 1837-1846.

[16] Tian C, Zhou X, Ding Z L, Liu Q, Xie G X, Peng J W, et al. Controlled-release $\mathrm{N}$ fertilizer to mitigate ammonia volatilization from double-cropping rice. Nutr Cycl Agroecosyst, 2020; 199: 123-137.

[17] Geng J B, Sun Y B, Zhang M, Li C L, Yang Y C, Liu Z G, et al. Long-term effects of controlled release urea application on crop yields and soil fertility under rice-oilseed rape rotation system. Field Crops Res, 2015; 184: 65-73.

[18] Zheng W K, Zhang M, Liu Z G, Zhou H Y, Lu H, Zhang W T, et al. Combining controlled-release urea and normal urea to improve the nitrogen use efficiency and yield under wheat-maize double cropping system. Field Crops Res, 2016; 197: 52-62.

[19] Xu X, He P, Yang F, Ma J C, Pampolino M F, Johnston A M, et al Methodology of fertilizer recommendation based on yield response and agronomic efficiency for rice in China. Field Crop Res, 2017; 206: 33-42.

[20] Miller W P, Miller D M. A micro-popette method for soil mechanical analysis. Commum. Soil Sci. Plant Anal, 1987; 18(1): 1-15.

[21] Bremner J M, Mulvaney C S. Nitrogen-total. In: Page A L, Miller R H, Keeney D R (Ed.). Methods of soil analysis, Part 2, chemical and microbial properties. Agronomy Monograph 9. Agronomy Society of America, Madison, Wisconsin, 1982; pp.595-624.

[22] Sinha S K, Rani M, Bansal N, Gayatri, Venkatesh K, Mandal P K. Nitrate starvation induced changes in root system architecture, carbon: nitrogen metabolism, and miRNA expression in nitrogen-responsive wheat genotypes. Appl Biochem Biotechnol, 2015; 177: 1299-1312.

[23] Kandeler A, Gerber H. Short-term assay of soil urease activity using colorimetric determination of ammonium. Biol. Fertil. Soils, 1988; 6: 68-72.

[24] Li Z L, Liu Z G, Zhang M, Li C L, Li Y C, Wan Y S, et al. Long-term effects of controlled-release potassium chloride on soil available potassium, nutrient absorption and yield of maize plants. Soil Tillage Res, 2020; 196 104438. doi: 10.1016/j.still.2019.104438.

[25] Wilding L P. In: Nielson D R, Bouma J (Ed.). Spatial variability: Its documentation, accommodation and implication to soil surveys. Soil Spatial Variability, Purdoc, Wageningen, 1984; pp.166-193.

[26] Skiba U, Wainwright M. Urea hydrolysis and transformations in coastal dune sands and soil. Plant Soil, 1984; 82: 117-123.

[27] Galloway J N, Townsend A R, Erisman J W, Bekunda M, Cai Z, Freney J, Martinelli L A, et al. Transformation of the nitrogen cycle: recent trends, questions, and potential solutions. Science, 2008; 320(5878): 889-892.

[28] Marchive C, Rounier F, Castaings L, Brehaut V, Blondet E, Colot V, et al Nuclear retention of the transcription factor NLP7 orchestrates the early response to nitrate in plants. Natture Communications, 2013; 4(1): 1713. doi: $10.1038 /$ ncomms 2650 .

[29] Liu F, Xu Y R, Chang K X, Li S, Liu Z, Qi S, et al. The long noncoding RNA T5120 regulates nitrate response and assimilation in Arabidopsis. New Phytol, 2019; 224(1): 117-132.

[30] Li P E, Lu J W, Wang Y. Nitrogen losses use efficiency and productivity of early rice under controlled-release urea. Agr Ecosyst Environ, 2018; 251: 78-87.

[31] Zheng W, Liu Z, Zhang M, Shi Y, Zhu Q. Improving crop yields, nitrogen use efficiencies and profits by using mixtures of coated controlled-released and uncoated urea in a wheat-maize system. Field Crop Res, 2017; 205: 106-115.

[32] Cui Z, Zhang H, Chen X, Zhang C, Ma W, Huang C, et al. Pursuing sustainable productivity with millions of smallholder farmers. Nat. Cell Biol, 2018; 555: 363-366.

[33] Sosulski T, Szara E, Szymanska M, Stępień W. N2O emission and nitrogen and carbon leaching from the soil in relation to long-term and current mineral and organic fertilization: A laboratory study. Plant Soil Environ, 2017; 63: 97-104.

[34] Incrocci L, Maggini R, Cei T, Gcrmassi G, Botrini L, Filippi F, et al. Innovative controlled release polyurethane-coated urea could reduce $\mathrm{N}$ leaching in tomato crop in comparison to conventional and stabilized fertilizers. Agronomy, 2020; 10: 1827. doi: 10.3390/ agronomy10111827.

[35] Zaman M, Saggar S, Blennerhassett J D, Singh J. Effect of urease and nitrification inhibitors on $\mathrm{N}$ transformation, gaseous emissions of ammonia and nitrous oxide pasture yield and $\mathrm{N}$ uptake in grazed pasture system. Soil Biology \& Biochemistry, 2009; 41(6): 1270-1280.

[36] Gang H, Wang Z, Li F, Dai J, Ma X, Li Q, et al. Soil nitrate-N residue, loss and accumulation affected by soil surface management and precipitation in a winter wheat-summer fallow system on dryland. Nutrient Cycling in Agroecosystems, 2016; 106(1): 31-46.

[37] Allison V J, Condron L M, Peltzer D A, Richardson S J, Turner B L. Changes in enzyme activities and soil microbial biomass community composition along carbon and nutrient gradients at the Franz Josef chronsequence, New Zealand. Soil Biology and Biochemistry, 2007; 39(7): 1770-1781. 
[38] Dai J, Wang Z, Li M, He G, Li Q, Chao H, et al. Winter wheat grain yield and summer nitrate leaching: Long-term effects of nitrogen and phosphorus rates on the Loess Plateau of China. Field Crops Research, 2019; 196: 180-190.

[39] Li T Y, Zhang W F, Yin J, Chadwick D, Norse D, Lu Y, et al. Enhanced-efficiency fertilizer are not a panacea for resolving the nitrogen problem. Global Change Biology, 2018; 24: 511-521.

[40] Shaviv A. Advances in controlled-release fertilizers. Advances in Agronomy, 2001; 71: 1-49.

[41] Guo J M, Wang Y H, Blaylock A D. Mixture of controlled release and normal urea to optimize nitrogen management for high-yielding $(>15 \mathrm{Mg}$ $\mathrm{ha}^{-1}$ ) maize. Field Crops Res, 2017; 204: 23-30.

[42] Gao X, Li C, Zhang M, Li T, Lu Y, Liu L. Controlled release urea improved crop yields and mitigated nitrate leaching under cotton-garlic intercropping system in a 4-year field trial. Soil Tillage Res, 2018; 175: $158-167$.

[43] Mikula K, Izydorczyk G, Skrzypaczak D, Mironiuk M, Moustakas K, Witek-Krowiak A, et al. Controlled release micronutrient fertilizers for precision agriculture-A review. Science of the Total Environment, 2020; 712: 136365. doi: 10.1016/j.scitotenv.2019.136365.

[44] Tian X, Li C, Zhang M, Li T, Lu Y Y, Liu L F. Controlled release urea improved crop yields and mitigated nitrate leaching under contton-garlic intercropping system in a 4-year field trial. Soil Tillage Res, 2018; 175 . $158-167$.

[45] Tang L, Sun H R, Sun R X, Niu Y N, Song J R, Li S Q, et al. Optimized nitrogen application increases soil water extraction by changing in-season maize root morphology and distribution in rainfed farmland. Agronomy, 2020; 10(10): 1606. doi: 10.3390/agronomy10101606. 